\title{
Acceleration and delay of sexual maturation in female house mice previously selected for early and late first vaginal oestrus
}

\author{
L. C. Drickamer \\ Biology Department, Williams College, Williamstown, Massachusetts 01267, U.S.A.
}

\begin{abstract}
Summary. Female mice previously selected for early and late sexual maturation were tested to determine whether they retained flexibility in age of puberty in response to pheromonal and social cues. First vaginal oestrus in fast-maturing females could be delayed but not accelerated by social cues. Conversely, puberty in slow-maturing females could be accelerated in their sexual development, but not delayed. Two additional experiments demonstrated that mice from the fast- and slow-maturing lines retained the capacity to accelerate and delay puberty via pheromonal and social cues.
\end{abstract}

\section{Introduction}

Sexual maturation of young female mice is accelerated by the presence of an adult male mouse or urine from intact adult males (Vandenbergh, 1967, 1969; Kennedy \& Brown, 1970; Bronson \& Maruniak, 1975). This acceleration is due to at least two factors, a urinary pheromone (Colby \& Vandenbergh, 1974) and synergistic social cues associated with the presence of an intact adult male (Drickamer, 1974a, 1975; Bronson \& Maruniak, 1975). Puberty is delayed in young female mice caged in groups and in females caged alone and exposed to urine from grouped females (Andervont, 1944; Drickamer, 1974b; McIntosh \& Drickamer, 1977).

These acceleration and delay effects also occur in wild Mus musculus (Drickamer, 1979) and the pheromones are produced in wild stocks of Mus (Massey \& Vandenbergh, 1980, 1981). These pheromones may contribute to a density-dependent feedback loop influencing generation time as part of a population regulation mechanism in house mice and possibly other small rodents (Drickamer, 1981a).

Another proposed mechanism of population regulation in rodents involves short-term changes in genotype with effects on behaviours related to population control. Chitty (1967) proposed a model involving selection for changes in aggression. The model was modified slightly by Krebs, Gaines, Keller, Myers \& Tamarin (1973) to incorporate behaviour relating to spacing and dispersal. Drickamer $(1981 \mathrm{~b})$ has found that it is possible to select mice for age at first vaginal oestrus, causing dramatic alteration in the age of puberty in only 3-4 generations of selection. Population regulation in house mice (and other rodents) could also, therefore, involve short-term selection which alters the age of sexual maturation and thus lengthens or shortens generation time.

It is also possible that these suggested mechanisms are operative separately or jointly in rodent populations. In this context several questions arise: (1) is it possible to induce further acceleration or delay of puberty in stocks of laboratory mice which have been previously 
selected for early and late puberty, and (2) do males and females of the selected lines retain the capacity to produce and excrete the pheromones which accelerate or delay puberty? The present study attempted to answer these questions.

\section{Materials and General Methods}

The mice used were from three stocks; a basic laboratory stock (herein designated B) of closed colony ICR/Alb house mice (Mus musculus) and two selected stocks (see Drickamer, 1981b), one bred for 6 generations for earlier first vaginal oestrus (mean age $=28.0$ days; designated $F$ ), and one bred for 6 generations for later first vaginal oestrus (mean age $=47.8$ days; designated S). All mice were housed in polypropylene cages measuring $15 \times 28 \times 15 \mathrm{~cm}$ with opaque sides and fitted wire lids. The bedding of wood shavings was changed once each week. Wayne Lab-Blox and water were supplied ad libitum. The colony and experimental rooms were maintained at $21-25^{\circ} \mathrm{C}$ and $30-60 \%$ relative humidity with a $12 \mathrm{~h}$ light $/ 12 \mathrm{~h}$ dark daily cycle with lights on from 06:00 to 18:00 h.

Matings within each stock were used to produce test subjects. Pregnant mice were isolated in individual cages during the last week of gestation. All cages were then checked daily, and births were recorded. On the day after birth each litter was counted and all young were sexed. Each litter was reduced to 10 young, at least 3 of which were males. Litters of less than 10 young were discarded. Mice were weaned at 21 days after birth and were immediately assigned to a treatment group by a random sequence.

Beginning at 21 days of age each test mouse was examined for vaginal perforation. Starting on the day of vaginal perforation a vaginal smear was taken each day until the occurrence of first oestrus. The smears were examined immediately with the light microscope and the criteria for oestrus were those used by Rugh (1968) and Vandenbergh (1969), i.e. 90-100\% cornified cells.

\section{Detailed Methods and Results}

\section{Experiment $I$}

Methods. The test subjects were 216 mice from each of the 3 stocks and they were assigned at random on Day 21 of age to a treatment group: mice in Group 1 were housed alone as controls; those in Group 2 were caged with an intact adult male; those in Group 3 were housed alone and painted daily on the external nares with $0.005 \mathrm{ml}$ urine from individually caged intact adult males; mice in Group 4 were housed as a group of 8/cage and those in Group 5 were housed alone and painted daily on the external nares with $0.005 \mathrm{ml}$ urine from grouped (8/cage) intact adult female mice. In Group 4, one female/cage was tested; she was selected at random while the other cagemates were from Stock B and were not tested. There were 18 test mice per group for each of the 3 stocks. The urine volumes were applied by means of a Hamilton syringe.

Males used for caging with females (Group 2) and all the males and females used for collection of excreted urine were from Stock B. Urine for treatment of mice in Groups 3 and 5 was collected fresh each day by holding donor mice (5-10/day) over a Petri dish and gently squeezing the flanks. Each test mouse was monitored as described in the 'General Methods' until the occurrence of first vaginal oestrus.

Results. A two-way analysis of variance (3 stocks $\times 5$ groups) was performed on the data for age at first vaginal oestrus. The main factor for stocks was significant $(F=112 \cdot 34$; d.f. $=2,255$; $P<0.001$ ). Examination of the data (Table 1) reveals that the Stock $\mathrm{F}$ mice matured earlier and Stock $\mathrm{S}$ mice later than did those of Stock B regardless of treatment. The main factor for treatments was also significant $(\mathrm{F}=83 \cdot 37$; d.f. $=4,255 ; P<0 \cdot 001)$. For Stock B mice, those in 
Group 2 matured the earliest followed by those in Groups 3 and 1; females in Groups 4 and 5 attained first oestrus later.

Table 1. Age at first vaginal oestrus in three stocks of house mice

\begin{tabular}{|c|c|c|c|}
\hline \multirow[b]{2}{*}{ Group } & \multicolumn{3}{|c|}{ Age at first vaginal oestrus (days) } \\
\hline & Stock B & Stock F & Stock S \\
\hline 2 (male present) & $27.4 \pm 0.4^{a *}$ & $27 \cdot 6 \pm 0.4^{a *}$ & $33.7 \pm 0.4^{\mathrm{a}}$ \\
\hline 3 (male urine painted daily) & $30.7 \pm 0.4^{a *}$ & $28 \cdot 1 \pm 0 \cdot 6^{\mathrm{a} *}$ & $37.4 \pm 0.6^{\mathrm{b}}$ \\
\hline 1 (control: female alone) & $35.5 \pm 0.5^{b}$ & $29.0 \pm 0.6^{8}$ & $44 \cdot 1 \pm 1 \cdot 2^{c}$ \\
\hline 4 (females grouped) & $39.1 \pm 0.5^{c}$ & $34.8 \pm 0.5^{b}$ & $45 \cdot 1 \pm 1 \cdot 0^{\mathrm{c}}$ \\
\hline 5 (female urine painted daily) & $39.6 \pm 0.6^{c}$ & $34 \cdot 1 \pm 0.7^{b}$ & $43 \cdot 3 \pm 1 \cdot 4^{\mathrm{c}}$ \\
\hline
\end{tabular}

Values are mean \pm 1 s.e.m. for 18 mice at each value.

Within stocks, values with different superscript letters are significantly different, $P<0.05$ (Duncan's New Multiple Range Test).

For horizontal rows each value not marked $\left(^{*}\right)$ is significantly different $(P<0.05)$ from all other values in that row.

For Stock $\mathrm{F}$ mice, females in Groups 1, 2 and 3 all reached first vaginal oestrus earlier than did females in Groups 4 and 5. First vaginal oestrus occurred earliest in Stock $\mathbf{S}$ mice in those in Group 2, followed by those in Group 3; the time for Groups 1, 4 and 5 was much greater.

The interaction factor for stocks $\times$ groups was also significant $(F=5.28$; d.f. $=8,255$; $P<0.001$ ). Examination of the data in Table 1 reveals several key patterns. Male acceleration of puberty occurred for mice of Stocks B and S but not for those of Stock F. Conversely, the delay of maturation brought about by grouping females or treatment with urine from grouped females occurred in mice of Stocks B and F but not in those of Stock S.

\section{Experiment $I I$}

Methods. At Day 21 of age 75 mice from Stock B were assigned at random to treatment groups: in Group 1 mice were caged alone and painted each day on the external nares with $0.005 \mathrm{ml}$ water; in Group 2 each female was caged with an intact adult male from Stock F; mice in Group 3 were caged alone and painted daily on the external nares with $0.005 \mathrm{ml}$ urine from Stock F males; in Group 4 females were caged in groups of 8, one Stock B test mouse and 7 Stock $\mathbf{F}$ females of the same age; in Group 5 females were caged alone and painted daily on the external nares with $0.005 \mathrm{ml}$ urine from grouped, adult, Stock $\mathrm{F}$ females. The males used for urine collection for Group 3 were caged individually 3 weeks before the experiment. Grouped females used as urine donors for Group 5 were caged in groups of 8,3 weeks before the experiment. For both treatments urine was collected as described in Exp. I. All test mice were monitored until the occurrence of first vaginal oestrus.

Results. As shown in Table 2 first vaginal oestrus occurred significantly earlier in Group 2 than in the other groups; females in Groups 1 and 3 matured earlier than those in Groups 4 and 5 .

\section{Experiment III}

Methods. The methods and procedures for Exp. III were the same as for Exp. II except that males and females from Stock $\mathrm{S}$ were used as stimulus animals and urine donors.

Results. The order for age at first vaginal oestrus was the same as that for Exp. II: Group 2, Group 3, Group 1 and Groups 4 and 5 (Table 2). 
Table 2. Age (days) at first vaginal oestrus in house mice of Stock B exposed to animals (or their urine) of Stocks $\mathrm{F}$ and $\mathrm{S}$

\begin{tabular}{lcc}
\hline \multicolumn{1}{c}{ Group } & Exp. II: Stock F & Exp. III: Stock S \\
\hline 2 (male present) & $28 \cdot 9 \pm 0 \cdot 7^{\mathrm{a}}$ & $29 \cdot 3 \pm 0 \cdot 6^{\mathrm{a}}$ \\
3 (male urine painted daily) & $30 \cdot 9 \pm 0 \cdot 8^{\mathrm{b}}$ & $31 \cdot 5 \pm 0 \cdot 5^{\mathrm{b}}$ \\
1 (control, female alone) & $34 \cdot 3 \pm 0 \cdot 8^{\mathrm{c}}$ & $34 \cdot 7 \pm 0 \cdot 6^{\mathrm{c}}$ \\
4 (females grouped) & $39 \cdot 5 \pm 1 \cdot 1^{\mathrm{d}}$ & $38 \cdot 2 \pm 1 \cdot 2^{\mathrm{d}}$ \\
5 (female urine painted daily) & $38 \cdot 9 \pm 0.4^{\mathrm{d}}$ & $38 \cdot 8 \pm 0 \cdot 6^{\mathrm{d}}$ \\
\hline
\end{tabular}

Values are mean \pm 1 s.e.m. for 15 mice/group.

Within experiments, values with different superscript letters are significantly different, $P<0.05$. For Exp. II, F $=24.41$, d.f. $=4,70, P<0.01$. For Exp. III, $\mathrm{F}=23.475$, d.f. $=4,70, P<0.01$.

\section{Discussion}

The foregoing experiments lead to two major conclusions: (1) mice from Stocks $\mathrm{F}$ and $\mathrm{S}$ do not have a fixed age of puberty and the age of first oestrus can be altered by pheromonal/social cues; and (2) males and females from Stocks $F$ and $S$ retain the capacity to accelerate and delay puberty in young female mice by pheromones and related social cues.

The results of Exp. I showed that puberty was delayed in Stock F females by treatment with urine from grouped females or caging in a group, but first oestrus could not be accelerated relative to the norm for Stock $\mathrm{F}$ females. Conversely, for Stock $\mathrm{S}$ females puberty was accelerated by caging with a male or painting daily with male urine, but first oestrus could not be further delayed by grouping or treatment with urine from grouped females. Thus a degree of flexibility is retained by mice of both stocks for the conditions used here, although with respect to the pheromonal and social cues tested it is apparent that the lower limit for Stock F mice and the upper limit for Stock S mice have been approached through the 6 generations of selection. It could be, however, that tests of other factors (e.g. daylength, diet) which affect the age of puberty would show that the lower and upper limits have not yet been reached.

The finding that puberty in Stocks $\mathrm{F}$ and $\mathrm{S}$ can still be affected by pheromonal and social treatments has several consequences. The existence of some flexibility, in that early and late maturation are not genetically fixed, suggests that reverse selection would be possible. That is, fast-maturing mice can be successfully selected for later puberty and slow-maturing females can be selected for earlier sexual maturation. If selection for puberty is to be considered a valid mechanism for population regulation, a reversal of selection should be demonstrable and this is currently being tested.

From the data of Massey \& Vandenbergh $(1980,1981)$ it now seems likely that pheromonal cues do operate to affect sexual maturation and hence generation time in feral mice of the genus Mus. It seems possible that both a genetic selection type mechanism and the accleration and delay of puberty could be operative in terms of population regulation. The present study and that on selection (Drickamer, 1981b) suggest that selection as a means of altering puberty and hence generation time could function in feral mice. However, when selection has produced laboratory mice that mature at the fast or slow extremes, only those social cues which tend to produce a mean age of puberty similar to that for unselected, untreated Stock B mice are effective. It therefore appears that both types of processes, short-term genetic selection and pheromonalsocial cues, could be involved in population regulation via effects on generation time. A selection process like that proposed by Chitty (1967) or Krebs et al. (1973) affecting sexual maturation would be one possible model incorporating these findings.

Experiments II and III demonstrated that the selection over 6 generations has not altered the ability of females or males of either selected stock to accelerate or delay first vaginal oestrus in 
females. While only the females were actually selected in the original study (Drickamer, 1981b), it is possible that the genetic effects would also show up in sibling males and these should also be tested. Selection for earlier or later first vaginal oestrus has not influenced in any measurable fashion the pheromonal and social effects leading to acceleration or delay of puberty in young females.

This research was supported by Grant No. HD-08585 (NIH) from the United States Public Health Service. I thank Mrs Susan Nagahashi for technical assistance.

\section{References}

Andervont, H.B. (1944) Influence of environment on mammary cancer in mice. J. natn. Cancer Inst. 4, 579-581.

Bronson, F.H. \& Maruniak, J.A. (1975) Male-induced puberty in female mice: evidence for a synergistic action of social cues. Biol. Reprod. 13, 94-98.

Chitty, D. (1967) The natural selection of self-regulatory behavior in animal populations. Proc. Ecol. Soc. Aust. 2, 51-78.

Colby, D.R. \& Vandenbergh, J.G. (1974) Regulatory effects of urinary pheromones on puberty in the mouse. Biol. Reprod. 11, 268-279.

Drickamer, L.C. (1974a) Sexual maturation of female house mice: social inhibition. Dev. Psychobiol. 7, $257-265$.

Drickamer, L.C. (1974b) Contact stimulation, androgenized females and accelerated sexual maturation in female mice. Behav. Biol. 12, 101110.

Drickamer, L.C. (1975) Contact stimulation and accelerated sexual maturation of female mice. Behav. Biol. 15, 113-115.

Drickamer, L.C. (1979) Acceleration and delay of first vaginal estrus in wild stocks of Mus musculus. $J$. Mammal. 60, 215-216.

Drickamer, L.C. (1981a) Pheromones and reproduction in rodents. In Environmental Factors and Mammalian Reproduction, pp. 100-111. Eds D. P. Gilmore \& B. Cook. Macmillan Co., London.
Drickamer, L.C. (1981b) Selection for age of sexual maturation in mice and the consequences for population regulation. Behav. Neural Biol. 32, 82-89.

Kennedy, J.M. \& Brown, K. (1970) Effects of male odor during infancy on the maturation, behavior and reproduction of female mice. Dev. Psychobiol. 3, 179-189.

Krebs, C.J., Gaines, M.S., Keller, B.L., Myers, J.H. \& Tamarin, R.H. (1973) Population cycles in small rodents. Science, N.Y. 179, 35-41.

Massey, A. \& Vandenbergh, J.G. (1980) Puberty delay by a urinary cue from female house mice in feral populations. Science, N.Y. 209, 821-822.

Massey, A. \& Vandenbergh, J.G. (1981) Puberty acceleration by a urinary cue from male mice in feral populations. Biol. Reprod. 24, 523-527.

McIntosh, T.K. \& Drickamer, L.C. (1977) Excreted urine, bladder urine and the delay of sexual maturation in female house mice. Anim. Behav. 25, 999-1004.

Rugh, R. (1968) The Mouse: Its Reproduction and Development. Burgess Publishing Co., Minneapolis.

Vandenbergh, J.G. (1967) Effect of the presence of a male on the sexual maturation of female mice. Endocrinology 81, 345-349.

Vandenbergh, J.G. (1969) Male odor accelerates female - sexual maturation in mice. Endocrinology 84, 658660.

Received 21 November 1980 